EWELINA MILART

ORCID 0000-0003-2201-7324

Uniwersytet im. Adama Mickiewicza

$w$ Poznaniu

\title{
INTERNET \\ W PLACÓWCE OPIEKUŃCZO-WYCHOWAWCZEJ
}

\begin{abstract}
AвSTRAct. Milart Ewelina, Internet w placówce opiekuńczo-wychowawczej [The Internet in an Educational and Care Facility]. Studia Edukacyjne nr 58, 2020, Poznań 2020, pp. 315-328. Adam Mickiewicz University Press. ISSN 1233-6688. DOI: 10.14746/se.2020.58.17

This paper aims to present the specifics of the Blessed M. Karłowska Care and Education Home for Girls in Poznań. At the beginning of my deliberations I referred to the rules prevailing in the institution. I have presented a number of restrictions that result from the internal rules of the center. I described the possibilities of using the Internet which result from prevailing restrictions. I moreover indicated the forms and ways of foster children's use of the Internet and referred to theoretical reflections on the teenagers' use of the Internet.
\end{abstract}

Key word: Internet, teens, care and education home, social media

\section{Wprowadzenie}

Internet spełniając wiele funkcji, staje się coraz bardziej potrzebny i użyteczny. Szczegółowe zastosowanie Internetu przedstawiła E. Chuchro, wyróżniając następujące jego funkcje:

- informacyjną - przekazuje informacje w łatwy, dostępny sposób;

- kształcącą - rozwija zasób wiadomości poprzez przekazywane treści;

- stymulującą - umożliwia rozbudzanie zainteresowań, hobby oraz motywacji;

- interpersonalną - pozwala na dzielenie się wspólnymi doświadczenia$\mathrm{mi}$, problemami;

- wychowawczą - ukazuje style życia;

- ludyczną - stanowi źródło rozrywki ${ }^{1}$.

${ }^{1}$ E. Chuchro, O walorach edukacyjnych i kulturotwórczych serwisu dla dzieci i młodzieży www. junior.repoerter.pl, [w:] Oblicza Internetu. Internet a globalne społeczeństwo informacyjne, red. M. Sokołowski, Elbląg 2005, s. 163-164. 
W odniesieniu do funkcji, jakie spełnia Internet, warto wskazać badania portalu Geminus, dotyczące pomiaru widowni w polskim Internecie. Raport zawiera między innymi listę najczęściej odwiedzanych stron oraz użytkowanych aplikacji mobilnych. W styczniu 2020 roku największą popularność zyskali właściciele następujących witryn i programów: Grupa Google, Grupa Wirtualna Polska, Facebook.com, Grupa RAS Polska, YouTube.com. Najwięcej internautów korzystało z Internetu za pomocą telefonów komórkowych. Przeciętny użytkownik spędził w tym czasie w Sieci blisko 2 godziny dzien$n^{2}{ }^{2}$. Na podstawie tych danych oraz własnej orientacji wokół specyfiki wymienionych witryn i programów, można stwierdzić, że Internet użytkowany jest głównie do celów informacyjnych, komunikacyjnych oraz rozrywkowych.

Sieć daje możliwość komunikacji, rozrywki, jak również stanowi ułatwienie $\mathrm{w}$ wielu codziennych czynnościach. Za pośrednictwem Internetu można płacić rachunki, oglądać filmy, czytać książki, uczyć się, rozmawiać z przyjaciółmi, uprawiać hobby, przeglądać najświeższe wiadomości i fakty. Można w nim również uzyskać poradę lekarza, zrobić zakupy. Przynosi zaspokojenie potrzeb: kontaktu z ludźmi, akceptacji, szacunku3 ${ }^{3}$. Jednakże, ma on również negatywne strony. Jednym z najbardziej istotnych, negatywnych skutków życia w Sieci jest internetoholizm - uzależnienie od Internetu, objawiające się przymusem spędzenia w nim czasu, dążeniem do stałego jego użytkowania. W sytuacji niemożliwości korzystania odczuwany jest dyskomfort. Internetoholizm stanowi formę patologicznego zachowania jednostki, związaną z uzależnieniem, zaburzeniami popędów w zachowaniu oraz nawykami ${ }^{4}$. Znaczącym i powszechnie występującym zjawiskiem dotykającym użytkowników Internetu jest cyberprzestępczość, cyberprzemoc, pornografia internetowa oraz hejt. Należy dodać, że Internet w swoim założeniu nie jest nacechowany pejoratywnie. Negatywne strony wynikają nie z samej jego koncepcji, ale ze sposobu korzystania z Sieci.

Ze względu na własne zainteresowania badawcze oraz wykonywaną pracę zawodową, podjęłam się napisania artykułu na temat użytkowania Internetu przez podopieczne Domu Opiekuńczo-Wychowawczego dla Dziewcząt im. bł. Marii Karłowskiej w Poznaniu. Zatrudnienie na stanowisku wychowawcy umożliwia mi podzielenie się spostrzeżeniami odnośnie obecności globalnej sieci komputerowej w życiu dziewcząt.

Podstawą prowadzonych przeze mnie badań była metoda obserwacji bezpośredniej, polegająca na zbieraniu informacji na temat faktów i danych za

${ }^{2}$ Raport Geminus w Styczniu [dostęp: 20.02.2020]; http://pbi.org.pl/raporty/polscy-internauci-w-styczniu-2020/

3 A. Słysz, B. Arcimowicz, Przyjaciele w Internecie, Gdańsk 2009, s. 45.

${ }^{4}$ S. Kozak, Patologia cyfrowego dzieciństwa i młodości, Warszawa 2014, s. 142. 
pomocą spostrzeżeń ${ }^{5}$. Należy zaznaczyć, że obserwacja bezpośrednia stanowi formę badania realizowaną poprzez postrzeganie bezpośrednie ${ }^{6}$. Niezwykle ważną kwestią w wyborze tej metody jest jej naturalność, na co zwraca uwagę A. Góralski, który uwzględnia dwa aspekty naturalności. Po pierwsze, obserwowanie jest naturalnym sposobem poznawania świata dla człowieka. Po drugie, daje możliwości obserwacji zdarzeń w zakłóconym przebiegu ${ }^{7}$.

Dzięki użyciu metody obserwacji miałam możliwość zawarcia kontekstu zdarzenia. Podczas działań badawczych brałam pod uwagę ograniczenia dostępu do Internetu, wynikające z umieszczenia dziewcząt w placówce. W trakcie prowadzonych badań starałam się ukazać sposób korzystania z Internetu przez podopieczne Domu Opiekuńczo-Wychowawczego. Obserwacje prowadziłam w trakcie pracy zawodowej w placówce. Jako narzędzia posłużyły mi notatki obserwacyjne oraz analiza stron internetowych. Badania poszerzyłam o wywiad wolny bez planu. Moja aktywność podczas badania miała zarówno charakter fizyczny, jako że uczestniczyłam w życiu podopiecznych podczas obserwacji, oraz intelektualny, kiedy formułowałam pytania, analizowałam spostrzeżenia. Badania miały formę jawną, niejednokrotnie rozmawiałam z dziewczętami na temat sposobu korzystania z globalnej Sieci. Dzięki dobrej wiedzy na temat podmiotów obserwacji, systematyczność przeprowadzania badań oraz stałe rejestrowanie ich wyników, miałam możliwość zyskania większej poprawności obserwacji.

\section{Dom Opiekuńczo-Wychowawczy dla Dziewcząt im. bł. Marii Karłowskiej w Poznaniu - specyfika funkcjonowania}

Dom Opiekuńczo-Wychowawczy dla Dziewcząt im. bł. Marii Karłowskiej w Poznaniu działa na podstawie Ustawy o pomocy społecznej ${ }^{8}$ oraz Rozporządzenia Ministra Pracy i Polityki Społecznej w sprawie placówek opiekuńczo -wychowawczych ${ }^{9}$, jak też własnego Regulaminu Organizacyjnego. Ośrodek ma charakter domu dziecka i jest przeznaczony dla dziewcząt od 13. do 18. roku życia. Osoby kierowane do placówki muszą mieć orzeczenie o kształceniu specjalnym ze względu na zagrożenie niedostosowaniem społecznym. Do Domu nie są przyjmowane dziewczęta ze zdiagnozowaną niepełnosprawno-

\footnotetext{
${ }^{5}$ J. Gnitecki, Wprowadzenie do metod badań w naukach pedagogicznych, Poznań 2006, s. 163.

${ }^{6}$ A. Góralski, Metody badań pedagogicznych w zarysie, Warszawa 2009, s. 17.

7 Tamże. s. 15.

${ }^{8}$ Ustawa z 12 marca 2004 roku o pomocy społecznej (DzU 2004, nr 64, poz. 593).

${ }^{9}$ Rozporządzenie Ministra Pracy i Polityki Społecznej z 19 października 2007 r. w sprawie placówek opiekuńczo-wychowawczych (DzU 2007, nr 201, poz. 1455).
} 
ścią intelektualną oraz oczekujące dziecka. Potencjalnymi podopiecznymi są natomiast osoby wykazujące problemy wychowawcze lub dotknięte deficytami rozwojowymi. Podopieczne w przeszłości dokonywały kradzieży, wagarowały, zażywały substancje psychoaktywne, piły alkohol lub są od nich uzależnione, jak też przejawiają zaburzenia psychoseksualne. W placówce zostają umieszczane na podstawie decyzji sądu, interwencyjnie bądź prywatnie przez opiekunów. Dom Opiekuńczo-Wychowawczy jest placówką całodobową, znajduje się w nim 30 miejsc. Nauka szkolna odbywa się wyłącznie na terenie placówki, gdzie działa zarówno szkoła podstawowa, jak i gimnazjum.

Praca z podopiecznymi opiera się głównie na działalności pedagogicznej, psychologicznej oraz socjoterapeutycznej. Placówka kładzie nacisk na indywidualne podejście do podopiecznych. W Domu zatrudniona jest wykwalifikowana kadra nauczycieli, pedagogów, psychologów, specjalistów, którzy dostosowują tempo i rodzaj pracy do możliwości oraz potrzeb podopiecznych $^{10}$. Na terenie placówki oprócz pomocy pychopedagogicznej prowadzone są liczne zajęcia i koła zainteresowań, które dają możliwość poznania oraz rozwijania umiejętności. Dom prowadzony jest przez Zgromadzenie Sióstr Pasterek od Opatrzności Bożej. W związku z tym, że jest to placówka o charakterze religijnym, wychowanie odbywa się w nawiązaniu do wiary; codzienna modlitwa, udział $w$ nabożeństwach oraz uroczystościach pełnią istotną rolę w wychowaniu. Oddziaływania w placówce odnoszą się do systemu punktowego (kary i nagrody). Podopieczne za zachowanie otrzymują adnotacje z liczbą punktów dodatnich bądź ujemnych. W wyniku uzyskania pozytywnych wpisów, dziewczęta mają możliwość posiadania większej liczby przywilejów. Wśród nich wyróżnić można: dodatkowe wyjścia poza placówkę (w tym wyjścia bez opieki osoby dorosłej), możliwość gratyfikacji finansowej, także korzystania z Internetu, telefonu.

W placówce istnieje wiele ograniczeń, na przykład w zakresie samodzielnego opuszczania ośrodka. Wyjście poza teren odbywa się zazwyczaj w towarzystwie opiekuna lub wychowawcy. W placówce obowiązują również restrykcyjne reguły odnośnie korzystania z mediów. Podopieczne na co dzień posługują się wyłącznie telefonem przeznaczonym do wspólnego użytku, a z osobami najbliższymi mogą kontaktować się tylko za zgodą wychowawcy. Obowiązuje zakaz posiadania przez dziewczęta prywatnych telefonów komórkowych.

Przedstawione reguły stanowią jedynie fragment pełnego obrazu zasad panujących na terenie placówki. Wyodrębniłam najważniejsze normy, które będą pomocne $\mathrm{w}$ ukazaniu organizacji pracy, a przede wszystkim są odzwierciedleniem możliwości korzystania przez podopieczne z technologii mobilnych, w tym Internetu.

${ }^{10}$ Program profilaktyczny Domu Opiekuńczo-Wychowawczego dla Dziewcząt uczennic Gimnazjum im. bł. Marii Karłowskiej, Poznań 2005, ADP, stan na dzień: 01.05.2018. 


\section{Aktywność dziewcząt w Sieci}

Korzystanie z globalnej sieci komputerowej w świetle regulaminu DOW Jedną z zasadniczych reguł na terenie placówki jest wspomniany już zakaz korzystania z prywatnych telefonów komórkowych, komputerów oraz urządzeń elektronicznych. Jeżeli podopieczne takowe posiadają, urządzenia znajdują się w depozycie i są udostępniane jedynie w wyznaczonym czasie.

Korzystanie z Internetu przez dziewczęta odbywa się w następujących sytuacjach:

- $\mathrm{w}$ trakcie odwiedzin na terenie placówki, to jest 1-2 razy w miesiącu (kiedy urządzenie mobilne udostępniają osoby odwiedzające);

- podczas wspólnych wyjazdów, kiedy posiadane własne urządzenie jest udostępniane podopiecznej - w sytuacji wyjazdów integracyjnych dłuższych niż jeden dzień;

- w sytuacji posiadania przez podopieczną punktów dodatnich, kiedy może $\mathrm{w}$ ramach ich zgromadzenia korzystać $\mathrm{z}$ Internetu za pośrednictwem komputerów PC, przeznaczonych do wspólnego użytku (jednak wyłącznie w czasie weekendu);

- podczas zajęć w szkole, kiedy nauczyciel uzna za konieczne korzystanie z Internetu do celów edukacyjnych;

- jeżeli jest taka potrzeba $\mathrm{w}$ trakcie codziennej nauki - pod nadzorem wychowawcy ${ }^{11}$.

Podczas pracy z podopiecznymi Internet używany jest również przez pracowników placówki w sposób następujący:

- poprzez wspólne oglądnie filmów za jego pośrednictwem;

- umożliwia wspólne słuchanie muzyki i/lub oglądanie teledysków z jego udziałem;

- pomaga we wspólnej nauce z wykorzystaniem zasobów globalnej sieci komputerowej;

- służy do celów informacyjnych ${ }^{12}$.

Należy zwrócić uwagę, że istotny jest czas, jaki dziewczęta poświęcają w Internecie na naukę lub samodoskonalenie. W placówce obowiązuje zasada, aby podopieczne korzystały z tradycyjnych form poszukiwania wiedzy. W Domu istnieje bogaty zasób książek, encyklopedii, słowników, literatury naukowej. Ponadto, dziewczęta mogą korzystać z pomocy wychowawców oraz pedagoga, którzy prowadzą wiele zajęć wspierających. Poszukiwanie wiedzy w Internecie stanowi ostateczną formę nauki i występuje relatywnie rzadko.

${ }^{11}$ Regulamin wewnętrzny Domu Opiekuńczo-Wychowawczego dla Dziewcząt im. bł. Marii Karłowskiej w Poznaniu.

${ }^{12}$ Tamże. 
Jak już zaznaczyłam, na teranie placówki dziewczęta mają ograniczony czas korzystania z Internetu. Łączenie z globalną Siecią odbywa się głównie pod nadzorem wychowawcy, za pośrednictwem komputerów PC. Podczas wspólnych wyjazdów dziewczęta posiadają własne telefony, jednak wówczas czas korzystania z nich jest również ograniczony. Podopieczne mogą używać telefonów zwykle kilka godzin dziennie, lecz na noc urządzenia są oddawane wychowawcom. Podczas wspólnych wyjazdów, wycieczek dostrzegam, że dziewczęta niemal nie spuszczają telefonu z oka, stale telefonują, wykonują zdjęcia, rozmawiają, piszą, słuchają muzyki. Jedyny problem może stanowić limit pakietu danych Internetu oraz brak wystarczająco pojemnej baterii.

Wiele obserwacji można dokonać w trakcie odwiedzin dziewcząt przez osoby bliskie czy też podczas urlopowań bądź przepustek. Wtedy zwykle dziewczęta mają nieograniczony dostęp do telefonu. Widoczna jest ich aktywność na Facebooku poprzez nowe aktualizacje na kontach. Jako kadra placówki uwrażliwiamy osoby odwiedzające na dozowanie udostępniania telefonów dziewczętom. Zauważalna jest tendencja użyczania przez osoby bliskie telefonu w trakcie spotkań. Pomiędzy osobą odwiedzającą a podopieczną tworzy się często bariera komunikacyjna. Dziewczęta wykazują znaczne zainteresowanie światem Internetu, rozmowami z grupą znajomych, z którą na co dzień się nie spotykają. Dominuje wejście w świat wirtualny, fizycznie pozostając w przestrzeni realnej i ograniczanie się do lakonicznych rozmów.

Powyższe wytyczne w pewien sposób klaryfikują rzeczywistość dostępu do Sieci przez podopieczne Domu Opiekuńczo-Wychowawczego. Według raportu NASK: Nastolatki 3.0, 62,6\% nastolatków korzysta z wyszukiwarki Google do codziennej nauki ${ }^{13}$. Na podstawie przywołanych zasad w placówce, czas jaki Dziewczęta poświęcają na uczenie się za pośrednictwem Sieci jest relatywnie niewielki. Istotnym czynnikiem tego zjawiska są ograniczenia wynikające $\mathrm{z}$ regulaminu.

Nie ulega wątpliwości, że Internet jest powszechny wśród nastolatków w Polsce. Zjawisko to daje się zauważyć w zaprezentowanych badaniach NASK: Nastolatki 3.0. Jednakże, nie wszystkie przedstawione dane znajdują potwierdzenie $\mathrm{w}$ postępowaniu dziewcząt. Podopieczne podczas przebywania na terenie placówki, która pośrednio jest ich domem tymczasowym, należą do mało licznej grupy osób ujętej w badaniu NASK. Dziewczęta korzystają z Internetu kilka razy w miesiącu. Wśród podopiecznych znajdują się osoby, które z Internetu nie mogą korzystać lub mają taką możliwość, ale tylko do celów edukacyjnych. Zastrzeżenia co do korzystania z Internetu wynikają z wcześniejszych działań ryzykownych za pośrednictwem Sieci. Niektóre dziewczęta zanim trafiły do placówki wykazywały syndromy uzależnienia

${ }^{13}$ Nastolatki 3.0 raport z ogólnopolskiego badania uczniów, [dostęp: 20.06.2019] https:// www.nask.pl/download/1/1346/RAPORTNASTOLATKI3ONLINE.pdf. S.41 
od Internetu, komputera, nieprawidłowego (agresja, przemoc) korzystania z Sieci lub uwikłania w internetową pornografię.

\section{Formy aktywności dziewcząt w Sieci}

W związku z przywołanym wcześniej systemem punktowym, dziewczęta mają do wyboru dwa warianty korzystania $z$ Internetu podczas pobytu w placówce: słuchanie muzyki lub otwarte korzystanie z Sieci, w tym możliwość wejścia na portale społecznościowe. Oczywiście, forma korzystania z Internetu zależna jest od liczby uzyskanych punktów.

Jedna z elementarnych czynności wykonywanych przez podopieczne za pośrednictwem Internetu polega na słuchaniu muzyki. Z przeprowadzonej z dziewczętami rozmowy wynika, że znaczna ich większość podczas serfowania to czyni. Oczywiście, możliwość słuchania utworów muzycznych za pomocą Internetu nie jest jedynym wariantem. Podopiecznym udostępniane jest radio do wspólnego użytku, jednak w Sieci mają możliwość wyboru ulubionych wykonawców.

Do najbardziej popularnych stron internetowych odwiedzanych przez dziewczęta należy Facebook oraz Instagram, jak również modna jest aplikacja Snapchat. Portale społecznościowe służą przede wszystkim do utrzymania więzi z rodziną, grupą rówieśniczą oraz ze znajomymi. Aktywność dziewcząt na Facebooku polega głównie na udostępnianiu fotografii, udziale w dyskusjach, komentowaniu oraz reagowaniu na posty bliskich osób, czy też poszukiwaniu nowych znajomych. Duże znaczenie dla podopiecznych mają rozmowy za pośrednictwem Facebooka, które przybierają głównie formę pisaną. Instagram służy natomiast do publikowania fotografii oraz obserwacji kont innych osób. Młodsze podopieczne dużo czasu w Internecie poświęcają na gry online. Korzystają głównie z podstawowych gier, umieszczonych na darmowych platformach, a są to gry logiczne, strategiczne. Ponadto, niektóre dziewczęta za pośrednictwem Internetu dokonują zakupów.

\section{Kreowanie siebie i komunikacja}

W poniższych rozważaniach odniosę się do specyficznych zachowań w Sieci, jakie widoczne są wśród podopiecznych. Ze względu na wzmożoną kontrolę podczas korzystania z Internetu, a zarazem możliwość własnych obserwacji, można dostrzec istotne zachowania dominujące wśród dziewcząt.

Wyróżniająca aktywność, jak wspomniano, polega na słuchaniu muzyki i jednocześnie oglądaniu teledysków. Warto wzbogacić te informacje o motywy słuchania wybranych ścieżek dźwiękowych. Dziewczęta w przeprowadzonej rozmowie podały powody, dla których słuchają muzyki: ,jest ważna, pomaga się zrelaksować", ,jest częścią mnie", , ,jest ",odzwierciedleniem mojego samopoczucia”, , ,jest oderwaniem od świata rzeczywistego", „uspokaja mnie", „wspomnienia”, ,odprężam się", ,poprawia humor". Widać głównie 
funkcję odprężającą, relaksującą. Jednakże, muzyka stanowi tylko pewnego rodzaju tło podczas korzystania z Internetu, jako że dziewczęta większość czasu spędzają na portalach społecznościowych, jednocześnie słuchając wybranych utworów muzycznych.

Największą uwagę zwracają formy aktywności w mediach społecznościowych (social media). Tylko dwie podopieczne nie mają konta na Facebooku - jedna z powodu wieku, bowiem nie przekroczyła 13. roku życia, czego wymaga regulamin, a druga nie ma zgody matki na jego prowadzenie.

Kontynuując rozważania dotyczące aktywności dziewcząt w Sieci, należy zaznaczyć, że istotna jest również strona wizualna prowadzonych kont. Można bowiem zaobserwować następujące tendencje: podopieczne wykonują zdjęcia na potrzebę umieszczenia ich w Sieci; fotografie są specjalnie wykadrowane przed publicznym udostępnieniem, bardzo modny stał się ich retusz, każde zdjęcie jest precyzyjnie sprawdzane, a wszelkie defekty szczegółowo i starannie usuwane. Ponadto, fotografie wykonywane są w pełnym makijażu, chociaż podczas przebywania w placówce obowiązuje zakaz używania kosmetyków, jednak w trakcie przepustek dziewczęta dysponują taką możliwością. Niejednokrotnie dostrzegam, że zdjęcia podopiecznych nie odzwierciedlają ich realnego wizerunku. Poprzez zastosowany makijaż oraz odpowiedni retusz dziewczęta wyglądają na znacznie starsze ${ }^{14}$.

Egzemplifikacje powyższych rozważań można odnieść do wielu przykładów dostępnych na portalach społecznościowych. Oczywiście, zjawisko nie dotyczy wyłącznie podopiecznych Domu. Niejednokrotnie użytkownicy Internetu przekonują się, że fotografie zamieszczone przez ich znajomych znacznie odbiegają od realiów życia danych osób.

Poza publikacją fotografii dziewczęta dzielą się swoimi przemyśleniami, w formie odrębnych postów lub komentarzy. Podopieczne są bardzo aktywne w tej kategorii - dominują komentarze zdjęć osób bliskich czy dalszych. Zauważam tutaj tendencję fałszywych relacji. Na co dzień dziewczęta żyją w grupie i łatwo dostrzec przyjaźnie lub konflikty, sympatię lub jej brak. Jednak to co realne, nie zawsze odzwierciedla się w świecie wirtualnym. Wiele podopiecznych pomimo braku relacji z inną osobą w życiu realnym, adoruje drugą osobę w Internecie. Dziewczęta publikują wspólne fotografie, nadając im w opisie braterski i wdzięczny charakter. W tym miejscu widoczna jest też tendencja stałego komentowania wszelkich publikacji. Pod zdjęciami dominują komplementy, jak na przykład: "można się zakochać”, ",fajna <3”, , ,śliczności”, , moja siska” "ślicznotka” "cudo" „ładnie”. Każde z określeń stanowi odrębny komentarz, do którego autorki fotografii najczęściej ustosunkowują się pisząc „dziękuję”. Duże znaczenie w przypadku opublikowanych postów

${ }^{14} \mathrm{Z}$ uwagi na to, że jestem aktywnym użytkownikiem Sieci, mam możliwość obserwacji kont dziewcząt, jednak ustawienia prywatności często ograniczają dostęp do informacji. 
zdjęć ma informacja zwrotna. Liczba polubień, komentarzy jest bardzo znacząca. Wśród dziewcząt znajdują się osoby kupujące facebookowe polubienia na platformach handlowych. Zjawisko to staje się coraz bardziej popularne. Oczywiście, sytuacja ta nie dotyczy wszystkich dziewcząt; część z nich korzysta, wydawałoby się, w sposób odpowiedni, to znaczy - istnieje dostrzegalna spójność pomiędzy światem rzeczywistym a wirtualnym.

Poza opisanym nastawieniem do grona znajomych, w Sieci pojawiają się skrajnie odmienne zachowania. Portale społecznościowe stają się narzędziem agresji i przemocy. Podopieczne również przejawiają negatywne zachowania w Internecie, potrafią okazać agresję słowną, bywały też przypadki podszywania się pod inną osobę, kradzieże cudzych fotografii w celu wyrządzenia drugiej koleżance krzywdy, podając się na przykład za chłopaka. Powszechnym, negatywnym zachowaniem w Sieci wśród dziewcząt jest

hejterstwo (od ang. hate - nienawiść, nienawidzić) - forma dewiacyjnych zachowań podczas publicznych dyskusji internetowych. Polega na używaniu obelżywego języka, pogardliwej ocenie różnych zjawisk, znieważaniu zarówno rozmówców, jak też różnych innych podmiotów oraz na wyrażaniu agresji i nienawiści pod ich adresem ${ }^{15}$.

Należy zwrócić tutaj uwagę na język, jakim posługują się podopieczne Domu. Dostrzegam jego trzy najbardziej znaczące elementy. Po pierwsze, pisownia zawiera wiele błędów ortograficznych, interpunkcyjnych, językowych. Po drugie, używany język jest pełen slangu. Po trzecie, formy językowe urozmaicane są wieloma akronimami, emotikonami. Rzecz bardzo istotną stanowi kultura języka, jako że wiele dziewcząt bywa prowokowana lub sama prowokuje innych użyciem przekleństw w wypowiedziach publicznych.

W odniesieniu do powyższych uwag, warto przywołać myśli M. Konopczyńskiego, który pisze, że autoprezentacje młodzieży nieprzystosowanej społecznie są nieadekwatne do sytuacji, pokazywanie siebie jest ubogie w wyrażaniu własnego Ja. Wyznacznikami stają się cele ukazywane przez kierunki zaspokajania potrzeb oraz dobierane na podstawie doświadczeń socjalizacyjnych ${ }^{16}$. Podczas obserwacji zachowań dziewcząt w Sieci mogę odnaleźć potwierdzenie niniejszej teorii dotyczącej sposobu kształtowania tożsamości, a dokładnie autoprezentacji. „Przebiega w różnorodny sposób, kreowanie siebie w życiu realnym może zupełnie odbiegać od tożsamości wirtualnej”. S. Kozak wskazuje na autoprezentację w wirtualnym świecie, dzieląc ją na:

${ }^{15}$ M. Juza, Hejterstwo w komunikacji internetowej: charakterystyka zjawiska, przyczyny i sposoby przeciwdziatania, w: Profilaktyka społeczna i resocjalizacja 2015, 25, s. 29 [dostęp: 24.02.2019], http://cejsh.icm.edu.pl/cejsh/element/bwmeta1.element.desklight-2536802e-bb0f-446e-90ea -b3b74d9550a3/c/hejterstwo_w_komunikacji_internetowej.pdf.

${ }^{16}$ M. Konopczyński, Kryzysy resocjalizacji czy(li) sukces działań pozornych. Refleksje wokót polskiej rzeczywistości resocjalizacyjnej, Warszawa 2013, s. 144. 
- Ja realne - cechy rzeczywiste zarówno zewnętrzne, jak i wewnętrzne;

- Ja wirtualne - cechy, których nie posiadamy/wyobrażane, nadane za pomocą Internetu;

- Ja pożądane - cechy, które pragniemy posiadać ${ }^{17}$.

Nawiązując tym samym do rozważań na temat tożsamości, warto zwrócić uwagę na czynniki, które mogą wpływać na jej kształtowanie. B. Ostafińska -Molik prezentuje przesłanki będące wyznacznikiem jakości życia oraz zagrożeń dla młodego pokolenia lat 2000: zmiany ustrojowe, zmiany w zakresie mody, zmiany autorytetów, styl życia wyznaczany przez media ${ }^{18}$. Ostatni czynnik ma duże znaczenie w przypadku prezentowania własnego Ja w Sieci przez podopieczne Domu. Dziewczęta mają wiele punktów odniesienia, a Internet staje się dla nich wyznacznikiem pewnych trendów. Ponadto J. Bednarek pisze, że cyberprzestrzeń stała się egalitarnym medium, to znaczy wszyscy mogą w niej uczestniczyć i są traktowani jednakowo, bez względu na wygląd, kolor skóry, płeć, sprawność fizyczną. Globalna sieć komputerowa daje człowiekowi olbrzymią wolność, szczególnie zdolność do samokreacji ${ }^{19}$.

Podczas obserwacji kont na portalach społecznościowych należących do podopiecznych Domu zwróciłam uwagę na pozytywny odbiór zamieszczanych fotografii, wpisów. Z. Melosik zaznacza, iż jednym z zadań Facebooka jest przyniesienie kompensacji niedoboru statusu. Ludzie żyją w lęku przed pozycją społeczną, doświadczają poczucia niskiej pozycji społecznej, jest to spowodowane przede wszystkim brakiem akceptacji od innych. Monitorują swoje życie, aby dowiedzieć się, co inni o nich myślą ${ }^{20}$.

A. Andrzejewska wskazuje, że obecnie istnieje potoczny charakter komunikowania się młodzieży, wiążący się z używaniem specyficznego słownictwa, pełnego skrótów, znaków graficznych, akronimów. Poprawność pisania ulega zaniechaniu, ze względu na pośpiech ${ }^{21}$. M. Konopczyński wskazuje, że $\mathrm{w}$ procesie socjalizacji najistotniejszą rolę odgrywa język. Powołując się na słowa Bernsteina, pisze, że pomiędzy językiem a mową znajduje się struktura społeczna ${ }^{22}$. Te tendencje również widoczne są wśród podopiecznych Domu. Dziewczęta nie zwracają dużej uwagi na poprawną komunikację, porozumiewają się używając języka Sieci.

17 S. Kozak, Patologia cyfrowego dzieciństwa i młodości, s. 162.

${ }^{18}$ E. Wysocka, Dzieci i młodzież w niegościnnym świecie. Zagrożenia rozwojowe i społeczne, Warszawa 2000, s. 92.

${ }^{19}$ J. Bednarek, Człowiek w obliczu szans cyberprzestrzeni i świata wirtualnego, Warszawa 2014, s. 21.

${ }^{20}$ Z. Melosik, Kultura popularna i tożsamość młodzieży. W niewoli władzy i wolności, Kraków 2013, s. 240.

${ }^{21}$ A. Andrzejewska, Dzieci i młodzież w sieci zagrożeń realnych i wirtualnych. Aspekty teoretyczne i empiryczne, Warszawa 2014, s. 23.

${ }_{22}^{2}$ M. Konopczyński, Kryzysy resocjalizacji, s. 94-95. 
W niniejszym artykule zwróciłam uwagę na agresywne zachowania w Internecie i w związku z tym należy odnieść się do powodów ich występowania. A. Jaworska wskazuje na takie przyczyny agresji wśród dzieci i młodzieży, jak: frustracja, brak zależności emocjonalnej do rodziców, agresja przejawiająca się najbliższym otoczeniu, model wychowania autorytarnego, agresja stosowana wobec dziecka ze strony innych osób, agresja w mediach, zaburzony ośrodkowy system nerwowy, zaburzenia psychiczne, zaniżona samoocena ${ }^{23}$. Wiele ze wskazanych przez autorkę czynników dostrzegam wśród podopiecznych Domu. Ze względu na ich trudną historię, głównie spowodowaną wychowywaniem się $\mathrm{w}$ rodzinie dysfunkcyjnej, agresja oraz przemoc mogą narastać również w Internecie.

\section{Nastolatki w Sieci - dostępne wyniki badań}

Dostępne wyniki badań dotyczące sposobu korzystania z Sieci przez nastolatków są bardzo pomocne w ocenie oraz porównaniu sposobu użytkowania Internetu przez osoby o wolnym dostępie do Sieci oraz przez podopieczne Domu, które mają ograniczenia w dostępie do Internetu.

NASK, będący państwowym instytutem badawczym nadzorowanym przez Ministerstwo Cyfryzacji, prowadzi ogólnopolskie badania odnośnie praktyk, postaw i opinii wobec Internetu wśród nastolatków ${ }^{24}$. Nastolatki 3.0 Raport z ogólnopolskiego badania uczniów jest jednym z najbardziej popularnych i wnikliwych badań nad sposobem korzystania z Sieci przez nastolatków.

Podczas jego analizy zwróciłam uwagę na kilka ważnych wątków poruszanych $\mathrm{w}$ niniejszym artykule. Bardzo istotna kwestia dotyczy czasu, jaki nastolatkowie przeznaczają na korzystanie z Internetu. Większość respondentów zadeklarowała, że codziennie korzysta z Sieci kilka godzin - około 4 godzin i 12 minut (w poprzedniej edycji badania średnia ta wynosiła około 3 godziny i 40 minut) ${ }^{25}$.

Godne uwagi są dane dotyczące rodzaju aktywności dokonywanych przez nastolatków w Sieci. Wśród badanych najwięcej osób za jej pośrednictwem słucha muzyki $(65,4 \%)$, ogląda filmy i seriale $(62,1 \%)$, kontaktuje się ze znajomymi i/lub rodziną za pośrednictwem czatów (61\%), korzysta z portali społecznościowych (59,4\%). Duża liczba osób - ponad połowa (50,6\%) - korzysta z Internetu w celu odrabiania lekcji. Najmniej badanych poświęca czas

\footnotetext{
${ }^{23}$ A. Jaworska, Leksykon resocjalizacji, Kraków 2012, s.19.

${ }^{24}$ Nastolatki 3.0 Raport z ogólnopolskiego badania uczniów [dostęp: 20.06.2019], s. 10.

${ }^{25}$ Tamże. s. 6.
} 
na załatwianie spraw urzędowych, korzystanie z e-learningów oraz na kontakty z nauczycielami ${ }^{26}$.

Istotna kwestia pojawia się w przypadku miejsca korzystania z Sieci: 95,5\% badanych odpowiedziało, że korzysta z niej w domu, 32\% - w szkole, a w drodze/podróży - blisko $57 \%{ }^{27}$. Najbardziej popularne media społecznościowe, z których korzystają respondenci, stanowią: Facebook, Instagram, Twitter, Snapchat ${ }^{28}$.

Zestawiając wyniki badań NASK ze sposobem korzystania z Sieci przez podopieczne Domu Opiekuńczo-Wychowawczego, można przede wszystkim dostrzec różnice czasu poświęcanego na korzystanie z Internetu. Jak w przypadku badanych nastolatków, dotyczył on kilku godzin dziennie, tak w placówce Domu Opiekuńczo-Wychowawczego sięgał średnio miesięcznie (a nie dziennie) 3 godziny i 40 minut. Warto dodać, że część podopiecznych Domu nie ma dostępu do Internetu nawet przez kilka miesięcy. W przypadku badań NASK, takie osoby stanowią jedynie $0,6 \%$ respondentów ${ }^{29}$. Należy odnieść się również do rozkładu procentowego podejmowanych aktywności w Sieci. Podopieczne, podobnie jak respondenci, bardzo często słuchają w niej muzyki, jednak rzadziej oglądają filmy czy seriale. Jest to podyktowane ograniczeniami czasu w dostępie do Internetu. Możliwość korzystania z niego wolą poświecić (podobnie jak badani nastolatkowie) na kontakt ze znajomymi/rodziną oraz korzystanie z portali społecznościowych. Również relatywnie rzadko podopieczne Domu korzystają z Internetu do nauki pozaszkolnej. Natomiast, w przypadku najbardziej popularnych mediów społecznościowych dokonują tego samego wyboru co respondenci. Najwięcej podopiecznych korzysta z Facebooka. Wśród badanych nastolatków sięga to 83,4\%. Popularność YouTube'a (94\% badanych nastolatków) również jest widoczna wśród podopiecznych Domu. Większość z nich podczas serwowania po Internecie słucha muzyki bądź śledzi kanały za pomocą tego serwisu ${ }^{30}$.

\section{Zakończenie}

Internet jako globalna sieć komputerowa jest bardzo powszechny, dotyczy niemal każdej dziedziny życia i ma znaczenie w obszarze wychowania. Jego udostępnienie młodemu człowiekowi stanowi duże wyzwanie dla opiekuna. Bardzo ważne jest bezpieczne korzystanie z Sieci, dlatego osoby dorosłe

\footnotetext{
26 Tamże. s. 11.

27 Tamże. s. 13

28 Tamże. s. 19.

29 Tamże. s. 9.

30 Tamże, s. 19.
} 
powinny mieć świadomość ryzyka wiążącego się z wejściem w świat wirtualny. Internet może przynieść ryzyko uzależnienia. Nadmierne zaangażowanie w życie wirtualne może skutkować szeregiem kłopotów dla młodego człowieka, między innymi z koncentracją, pogorszeniem się nauki szkolnej, może wywołać agresję, czy huśtawki emocjonalne. Ważne jest, jak sądzę, nie tylko pilnowanie czasu spędzanego w Internecie, ale i sposobu z jego korzystania. To na rodzicach/opiekunach spoczywa odpowiedzialność, aby nauczyć młodego człowieka bezpiecznego sposobu korzystania z Internetu, komputera oraz urządzeń mobilnych.

Formy, cele oraz czas korzystania z Internetu w Domu Opiekuńczo-Wychowawczym dla Dziewcząt im. bł. Marii Karłowskiej w Poznaniu odbiega częściowo od statystyk dotyczących użytkowania Internetu przez obecnych nastolatków. Jest to związane z regulaminem obowiązującym na terenie placówki.

Nie można zapomnieć, o czym pisze M. Tanaś, że „świat mediów pozostawia głęboki ślad w umyśle dziecka. Współczesna generacja wyrasta w środowisku mediów w przeciwieństwie do pokoleń minionych"31. Jako wychowawca, osoba świadoma dobrych i złych stron Internetu, dostrzegam zalety dotyczące ograniczeń dostępu do globalnej Sieci dla podopiecznych. Kontakt z nią umożliwiany dziewczętom Domu w znacznej części spełnia niezbędne cele edukacji medialnej, która powinna przygotować odbiorcę między innymi do: uczenia się nowej technologii kształcenia, umiejętności selekcji informacji przekazywanych przez media, umiejętności praktycznego posługiwania się technologiami, kreowania programów edukacyjnych ${ }^{32}$.

Z uwagi na szereg zachowań dziewcząt przed umieszczeniem w placówce, które dotyczyły między innymi agresji, wczesnych inicjacji alkoholowych, seksualnych oraz innych form wskazujących na niedostosowane społeczne, placówka musi dbać o zapewnienie odpowiednich warunków opieki i wychowania, w tym zabezpieczanie dziewcząt przed ryzykownymi kontaktami za pośrednictwem Internetu.

Konkludując, posłużę się słowami M. Tanasia, który napisał, że media odgrywają bardzo istotną rolę w procesie socjalizacji, pomimo że może być ona pośrednia, to są jej istotnym źródłem poza rodziną, kręgiem znajomych, osób znaczących, szkoły, czy Kościoła. Autor ten dodaje, że problem istnieje w tym, że treści przekazywane przez media rzadko kiedy są zamierzone i realizowane w tym samym kierunku co działania wychowawcze ${ }^{33}$.

${ }^{31}$ M. Tanaś, Wychowanie a media, [w:] Pedagogika medialna, red. B. Siemieniecki, Warszawa 2007, s. 197.

32 S. Juszczyk, Cele i zadania technologii informacyjnej i edukacji medialnej, [w:] Tamże, s. 27.

33 M. Tanaś, Wychowanie a media, s. 197. 


\section{BIBLIOGRAFIA}

Andrzejewska A., Dzieci i młodzież w sieci zagrożeń realnych i wirtualnych. Aspekty teoretyczne i empiryczne, Warszawa 2014.

Bednarek J., Człowiek w obliczu szans cyberprzestrzeni i świata wirtualnego, Warszawa 2014.

Chuchro E., O walorach edukacyjnych $i$ kulturotwórczych serwisu dla dzieci $i$ młodzieży www. junior.repoerter.pl, [w:] Oblicza Internetu. Internet a globalne społeczeństwo informacyjne, red. M. Sokołowski, Elbląg 2005.

Gnitecki J., Wprowadzenie do metod badań w naukach pedagogicznych, Poznań 2006.

Jaworska A., Leksykon resocjalizacji, Kraków 2012.

Juszczyk S., Cele i zadania technologii informacyjnej i edukacji medialnej, [w:] Pedagogika medialna, red. B. Siemieniecki, Warszawa 2007.

Juza M., Hejterstwo w komunikacji internetowej: charakterystyka zjawiska, przyczyny $i$ sposoby przeciwdziałania, [w:] Profilaktyka społeczna i resocjalizacja 2015, [dostęp: 24.02.2019], http:/ / cejsh.icm.edu.pl/cejsh/element/bwmeta1.element.desklight-2536802e-bb0f -446e-90ea-b3b74d9550a3/c/hejterstwo_w_komunikacji_internetowej.pdf.

Konopczyński M., Kryzysy resocjalizacji czy(li) sukces działań pozornych. Refleksje wokót polskiej rzeczywistości resocjalizacyjnej, Warszawa 2013.

Kozak S., Patologia cyfrowego dzieciństwa i młodości, Warszawa 2014.

Melosik Z., Kultura popularna i tożsamość młodzieży. W niewoli władzy i wolności, Kraków 2013.

Nastolatki 3.0 Raport z ogólnopolskiego badania uczniów, [dostęp: 20.06.2019] https:// www.nask.pl/download/1/1346/RAPORTNASTOLATKI3ONLINE.pdf.

Program profilaktyczny Domu Opiekuńczo-Wychowawczego dla Dziewcząt uczennic Gimnazjum im. bł. Marii Karłowskiej, Poznań 2005, ADP, stan na dzień: 01.05.2018

Raport Geminus, Styczeń, http://pbi.org.pl/raporty/polscy-internauci-w-styczniu-2019/, [dostęp: 24.02.2019].

Regulamin wewnętrzny Domu Opiekuńczo-Wychowawczego dla Dziewcząt im. bł. Marii Karłowskiej w Poznaniu.

Rozporządzenie Ministra Pracy i Polityki Społecznej z 19 października 2007 r. w sprawie placówek opiekuńczo-wychowawczych (DzU 2007, nr 201, poz. 1455).

Słysz A., Arcimowicz B., Przyjaciele w Internecie, Gdańsk 2009, [dostęp: 24.02.2019] http:/ / pbi.org.pl/badanie-gemius-pbi/polski-internet-w-styczniu-2019/.

Statut Domu Opiekuńczo-Wychowawczego dla Dziewcząt im. bł. Marii Karłowskiej w Poznaniu, r. II §2, Poznań 2013, [dostęp: 30.03.2019].

Szczęsny W., Zarys resocjalizacji z elementami patologii społecznej i profilaktyki, Warszawa 2003.

Tanaś M., Wychowanie a media, [w:] Pedagogika medialna, red. B. Siemieniecki, Warszawa 2007.

Ustawa z 12 marca 2004 roku o pomocy społecznej (DzU z 2004, nr 64, poz. 593).

Wysocka E., Dzieci i młodzież w niegościnnym świecie. Zagrożenia rozwojowe i społeczne, Warszawa 2000. 